\title{
ANNUAL FLOOD ANALYSIS OF CISANGGARUNG WATERSHED IN CIREBON REGENCY
}

\author{
Abdul, MUIN \\ Faculty of Engineering \\ University Mercu Buana Bekasi, Indonesia \\ muins_near45@yahoo.com \\ Jantiara Eka, NANDIASA \\ Faculty of Engineering \\ University Mercu Buana Bekasi, Indonesia \\ jantiara@mercubuana.ac.id
}

\begin{abstract}
Cisanggarung River, a river in West Java Province, often experiences flooding. This study aims to discuss the magnitude of annual flood discharge that may occur in the Cisanggarung watershed. Rain data at each station in the Cisanggarung watershed from 2005 to 2017 were analyzed using descriptive-quantitative methods. Return period flood discharge 2, 5, 10, 20, and 50 years were compared to 2-yearly and monthly flood discharge. The results showed that the data followed the Log-Pearson Type III distribution. The return period flood discharge is: $Q 2=181.518 \mathrm{~m}^{3} / \mathrm{s}, Q 5=242.498 \mathrm{~m}^{3} / \mathrm{s}, Q 10=283.109 \mathrm{~m}^{3} / \mathrm{s}, Q 20=316.534$ $\mathrm{m}^{3} / \mathrm{s}, Q 50=373.369 \mathrm{~m}^{3} / \mathrm{s}, Q 100=412.425 \mathrm{~m}^{3} / \mathrm{s}, Q 200=452.013 \mathrm{~m}^{3} / \mathrm{s}$, dan $Q 1000=$ $546.683 \mathrm{~m}^{3} / \mathrm{s}$ by using the Nakayasu method. Based on the 2 annual maximum daily rains, 2005, 2007, 2009-2010, 2015, 2009-2017 has the potential to flood Q2, 2012 has the potential to flood Q5, and 2017 has the potential to flood Q10. According to maximum 2-daily monthly rainfall, in 2005-2007, January-April and November have the potential to flood Q2. December has the potential to flood Q10. These results are useful for flood control in the region to be more effective and accurate.
\end{abstract}

Keywords: Flood, Flood Discharge, Watershed, Re-Period, Cisanggarung River

\section{INTRODUCTION}

Flood is a condition where water is not accommodated in the drainage channel (river trough) or the flow of water is obstructed in the drainage channel, so that it overflows and inundates the surrounding area (floodplain). One of the flooding problems caused by natural factors is high rainfall and water flow in rivers that are hydrologically described as hydrographs with peak and volume of floods. Rainfall that falls above the watershed mostly becomes a direct runoff consisting of surface runoff and interflow. This kind of flow can produce high flood peaks. The event of maximum discharge or peak flooding is only a few moments, but can damage urban infrastructure facilities such as roads and bending, inundate settlements and rice fields, disrupt human activities and others.

Cisanggarung River is a river in West Java Province which is tipped south of the Darma Reservoir, Cageur Village, Darma District, Kuningan Regency and empties into the Java Sea. This river crosses Kuningan and Cirebon Regencies in West Java Province and Brebes Regency in Central Java Province. Every year, the Cisanggarung River will definitely experience flooding in several areas, one of which is Babakan Losari Lor Village, Pabedilan District, Cirebon Regency. Floods that hit the village had a height of 40-60 centimeters. This is because the location of the Village of Babakan Losari Lor is very close to the river. Even though there were no fatalities, this annual flood is of great concern and is certainly 
detrimental to the community such as crop failures, access to waterlogged roads, houses becoming dirty, residents' activities disrupted and others.

As an action to control floods in the area around the Cisanggarung watershed, annual flood analysis is carried out. This research will record the magnitude of annual flood discharge that may occur in the Cisanggarung River Basin. Predictions of flood discharge figures can be calculated from rain data at each of the nearest rain recording stations. From the station rainfall data for 13 years, from 2005-2017, an annual flood analysis can be done which is caused by daily rains, daily rains and maximum annual rains. Flood discharges with a return period of $2,5,10,20,50$ years will be compared with 2 yearly flood discharges and monthly flood discharges, so that it will be easier to socialize the risk of flooding for residents living in the Babakan Losari Lor region that are traversed by Cisanggarung river.

The results of this study can be useful as information in the field of civil engineering, especially regarding hydrology, namely annual flood analysis in a watershed. In addition, with this information, the local government can take consideration for maintenance and supervision of the Cisanggarung River Basin.

\section{RESEARCH METHODOLOGY}

This research was conducted by descriptive-quantitative method. Through this method, it is expected to be able to describe the events and conditions of annual floods and infer them in the discharge rate. The location of the Watershed that was reviewed in this study was the Cisanggarung downstream watershed. This study uses Cisanggarung watershed data from Losari Lor rain station in Pabedilan sub-district, Jatiseeng station in Ciledug sub-district which includes data on rainfall depth and river flow discharge. This study uses secondary data that is data that is not taken directly from data collectors, but through documents or other people. The data obtained were processed using Microsoft Excel and Auto CAD programs.

In the hydrological aspect, what needs to be obtained first is the annual maximum daily rainfall data from the rain recording station. Rainfall data analysis can be done with the Normal, Log Normal, Pearson, Log Pearson Type III, and Gumbel distribution methods [3].

Normal distribution or normal curve is also called the Gauss distribution. This distribution has a probability density function as follows:

where:

$$
P(X)=\frac{1}{\sqrt[\sigma]{2_{\pi}}} \exp \left[\frac{(x-\mu)^{2}}{2 \sigma^{2}}\right]-\infty \leq x \leq \infty
$$

$\mathrm{P}(\mathrm{X})=$ normal probability density function (normal curve ordinate),

$X \quad=$ continuous random variable,

$\mu \quad=$ average value of $X$,

$\sigma \quad=$ standard deviation of the value of $X$.

The formula commonly used for normal distribution is:

where:

$$
\mathrm{X}_{\mathrm{T}}=\overline{\mathrm{X}}+\mathrm{K}_{\mathrm{T}} \mathrm{S}
$$

$\mathrm{X}_{\mathrm{T}} \quad=$ the estimated value expected to occur with a $\mathrm{T}$-annual return period,

$\overline{\mathrm{X}} \quad=$ the average value of the counted sample,

$\mathrm{S}=$ standard deviation of the sample value,

$\mathrm{K}_{\mathrm{T}} \quad$ = frequency factor, is a function of the opportunity or return period and the type of

mathematical model of the opportunity distribution used for opportunity analysis [11].

The properties of normal distribution are the skewness coefficient equal to zero and

the value of the coefficient of kurtosis is close to three. In addition there are the following cumulative frequency distribution properties:

$\mathrm{PX}-\mathrm{S}=15.87 \%$

$P X \quad=50 \%$ 
$\mathrm{PX}+\mathrm{S}=84.14 \%$

Lognormal distribution is used if the values of the random variable do not follow the normal distribution, but the logarithmic value meets the normal distribution. The properties of the lognormal distribution are as follows:

Skewness Coefficient: $\mathrm{Cs}=\mathrm{Cv}^{3}+3 \mathrm{Cv}$

Kurtosis Coefficient : $\mathrm{Ck}=\mathrm{Cv}^{8}+6 \mathrm{Cv}^{6}+15 C \mathrm{v}^{4}+16 C v^{2}+3$

The Gumbel distribution has the following formula:

where:

$$
\mathrm{X}_{\mathrm{T}}=\overline{\mathrm{X}}+\mathrm{SK}
$$

$\mathrm{X}_{\mathrm{T}}=$ rain plan $(\mathrm{mm})$

$\overline{\mathrm{X}}=$ average value of rain

$\mathrm{S}=$ Standard deviation of rain data

$\mathrm{K}=$ Gumbel frequency factor $\left(\frac{\mathrm{Y}_{\mathrm{t}}-\mathrm{Y}_{\mathrm{n}}}{\mathrm{S}_{\mathrm{n}}}\right)$

Gumbel distribution has the following characteristics:

Skewness Coefficient $\quad: \mathrm{C}_{\mathrm{s}}=1.1396$

Kurtosis Coefficient $\quad: \mathrm{C}_{\mathrm{k}}=5.4002$

One of the distributions of a series of distributions developed and that concerns water resources experts is the Log Pearson Type III. Three important parameters in distribution analysis are average prices, standard deviations and slope coefficients. If the slope coefficient is zero, the distribution returns to the Normal Log distribution.

Probability test distribution (distribution) is done by the chi-square method to find out whether the selected distribution equation can represent the probability distribution of the analysis data sample [7]. To obtain the magnitude of flood discharges caused by river overflows, it is done by processing annual flood data using the Nakayasu method. Flood discharge is analyzed based on annual maximum 2 daily rainfall data.

\section{RESULTS AND DISCUSSION}

This study uses rainfall data from 2005-2017 from two representative rain stations namely the Losari Lor and Jatiseeng rain stations. This data is used as preliminary data for determining flood discharge (Table 1). Cisanggarung watershed annual rainfall data is cumulative rainfall data in a year.

Table 1. Clsanggarung watershed annual rainfall data

\begin{tabular}{ccc}
\hline \multirow{2}{*}{ Year } & \multicolumn{2}{c}{ Annual Rainfall $(\mathbf{I})(\mathbf{m m} /$ year $)$} \\
\cline { 2 - 3 } & Losari Lor & Jatiseeng \\
\hline 2005 & 2159 & 2667 \\
2006 & 1625 & 2477 \\
2008 & 1437 & 2010 \\
2009 & 430 & 647 \\
2010 & 1042 & 347 \\
2011 & 825 & 868 \\
2012 & 671 & 1061 \\
2013 & 1235 & 1867 \\
2014 & 500 & 530 \\
2015 & 927 & 1198 \\
2016 & 845 & 2407 \\
2017 & 2014 & 1911 \\
\end{tabular}

Source : Cirebon District Water Resources Management Agency 


\section{Determination of Annual Maximum Daily Regional Rainfall}

Determination of the maximum annual daily rainfall amount is done by taking data of annual maximum daily rainfall from each station on the same event day in the same year. Using maximum daily rainfall data from both stations (Appendix 1). Using the Thiessen Polygon method and selecting the largest value from the two observer data, the maximum annual daily rainfall rate is obtained as in Table 2. The data in Table 2 afterwards performed a statistical parameter test.

Table 2. Annual maximum daily regional rainfall

\begin{tabular}{cc}
\hline Year & Maximum Rain Area $(\mathbf{m m})$ \\
\hline 2005 & 67.540 \\
\hline 2006 & 93.951 \\
\hline 2007 & 64.263 \\
\hline 2008 & 54.049 \\
\hline 2009 & 82.340 \\
\hline 2010 & 50.666 \\
\hline 2011 & 39.185 \\
\hline 2012 & 78.283 \\
\hline 2013 & 127.964 \\
\hline 2014 & 37.191 \\
\hline 2015 & 60.553 \\
\hline 2016 & 76.518 \\
\hline 2017 & 62.390 \\
\hline
\end{tabular}

\section{Statistical Parameters}

After calculating the annual maximum daily rainfall, the suitability of the distribution test is carried out through statistical parameters such as the average value $(\bar{X})$, standard deviation (S), coefficient of variation (Cv), skewness coefficient (Cs), and coefficient kurtosis (Ck). The determination of this statistical parameter is done to find the corresponding maximum daily rainfall probability distribution. From the calculation results, the data follows the distribution of the Log Pearson Type III because all conditions are not met (see Table 3).

Table 3. Results of the selection of distribution types

\begin{tabular}{|c|c|c|c|}
\hline $\begin{array}{c}\text { Distribution } \\
\text { Type }\end{array}$ & Requirement & $\begin{array}{l}\text { Value of } \\
\text { coeff. }\end{array}$ & Conclusion \\
\hline \multirow{2}{*}{ Normal } & $\mathrm{Cs}=0$ & $\mathrm{Cs}=1.10$ & No \\
\hline & $\mathrm{Ck}=3$ & $\mathrm{Ck}=5.46$ & No \\
\hline \multirow[b]{2}{*}{ Log Normal } & $C v^{3}+3 C v \quad C s(\ln x)=0$ & $\mathrm{Cs}=0.11$ & No \\
\hline & $\begin{array}{c}C \mathrm{Ck}=C v^{8}+6 C v^{6}+15 C v^{4}+16 C v^{2}+3 \\
C k(\ln x)=3\end{array}$ & $\mathrm{Ck}=3.86$ & No \\
\hline \multirow[b]{2}{*}{ Pearson III } & Cs $>0$ & $\mathrm{Cs}=1.10$ & Yes \\
\hline & $\mathrm{Ck}=1.5 \mathrm{Cs}^{2}+3$ & $\mathrm{Ck}=5.46$ & No \\
\hline \multirow{2}{*}{$\begin{array}{c}\text { Log Pearson } \\
\text { III }\end{array}$} & \multirow{2}{*}{ If all requirements are not fulfilled } & $\mathrm{Cs}=0.11$ & Yes \\
\hline & & $\mathrm{Ck}=3.86$ & Yes \\
\hline \multirow{2}{*}{ Gumbell } & $\mathrm{Cs}=1.14$ & $\mathrm{Cs}=1.10$ & No \\
\hline & $\mathrm{Ck}=5.4$ & $\mathrm{Ck}=5.46$ & No \\
\hline
\end{tabular}

\section{Testing of Distribution Type}

The goodness of fittest test in Table 4 states that the type of Pearson Log Type III distribution from the annual maximum annual regional rainfall data is a good match. This can 
be seen in the value of $x^{2}$ count $(9.40)>x^{2}$ critical (5.991) which states that with a significance level of $5 \%$ chi-square test is accepted. That is, the maximum annual regional rainfall data available in Table 4 can represent other frequency data (distributing).

Table 4. Calculation of chi-square test of the log pearson III in cisanggarung watershed

\begin{tabular}{|c|c|c|c|c|c|}
\hline $\begin{array}{l}N \\
0\end{array}$ & Probability (P) & $\begin{array}{l}\text { Expecte } \\
\text { d } \\
\text { Frequen } \\
\text { cy (Ef) }\end{array}$ & $\begin{array}{l}\text { Ovserve } \\
\text { d } \\
\text { Frequen } \\
\text { cy (Of) }\end{array}$ & $\begin{array}{l}\text { Ef - } \\
\text { Of }\end{array}$ & $\begin{array}{l}\text { (Ef - } \\
\text { Of })^{2}\end{array}$ \\
\hline 1 & $\begin{array}{c}0.00<\leq 20.00 \\
P \leq\end{array}$ & 2.6 & 1 & 1.6 & 2.56 \\
\hline 2 & $\begin{array}{c}20.00<\leq 40.00 \\
P \leq\end{array}$ & 2.6 & 2 & 0.6 & 0.36 \\
\hline 3 & $\begin{array}{l}40.00<\leq 60.00 \\
P\end{array}$ & 2.6 & 4 & -1.4 & 1.96 \\
\hline 4 & $\begin{array}{c}60.00<80.00 \\
P\end{array}$ & 2.6 & 1 & 1.6 & 2.56 \\
\hline 5 & $\begin{array}{l}80.00<100.00 \\
P\end{array}$ & 2.6 & 4 & -1.4 & 1.96 \\
\hline \multicolumn{3}{|r|}{ Number } & 12 & & 9.40 \\
\hline
\end{tabular}

\section{Calculation of Rainfall Periods}

By using distribution equation of the log-Pearson Type III (Equation 4), the magnitude of the rain return period can be determined. Distribution coefficient of Log Person Type III $(G)$ is determined from the calculation of the slope coefficient. The slope coefficient value is 0.110 so that the corresponding $\mathrm{G}$ value will be obtained.

$$
\log X_{n}=L_{n} X_{i}+(G S)
$$

Table 5. Results of effective rain calculation over time periods

\begin{tabular}{ccccc}
\hline $\begin{array}{c}\text { Rain } \\
\text { Time Period }(\mathrm{T})\end{array}$ & 1 & 2 & 3 & 4 \\
\hline 2 & 10.399 & 8.024 & 3.787 & 3.466 \\
5 & 13.892 & 10.719 & 5.059 & 4.631 \\
10 & 16.218 & 12.514 & 5.907 & 5.406 \\
20 & 18.133 & 13.992 & 6.604 & 6.044 \\
50 & 21.389 & 16.504 & 7.790 & 7.130 \\
100 & 23.626 & 18.230 & 8.605 & 7.875 \\
1000 & 31.317 & 24.165 & 11.406 & 10.439 \\
\hline
\end{tabular}

The effective rain calculation is calculated by multiplying the return period rain rate by the value of the flow coefficient (0.396) [12]. The effective rain of the re-period period is generated by multiplying the value of the effective rain rate by the percentage distribution per hour within 4 hours [8]. The results have been tabulated (Table 5).

\section{Calculation of the Nakayasu Unit Hydrograph}

Due to the absence of hydrological data, to reduce the hydrographic unit, it is necessary to make a synthetic unit hydrograph based on the physical characteristics of the watershed. The width of the River Basin is $205.53 \mathrm{~km}^{2}$ and the length of the River (L) is $27.30 \mathrm{~km}$. The resulting hydrograph unit must be divided by the correction factor to make the hydrograph unit per one millimeter. The hydrographic unit correction factor is the ratio 
between the volume and the watershed area. The Nakayasu unit hydrograph unit obtained is multiplied by the rain distribution factor.

$\mathrm{Qp}$ is the peak flood discharge that occurs during peak time $(\mathrm{Tp})$ at $3.47 \approx$ hours. Then the time from the peak flood drops to 0.3 times the peak flood discharge (see Figure 1).

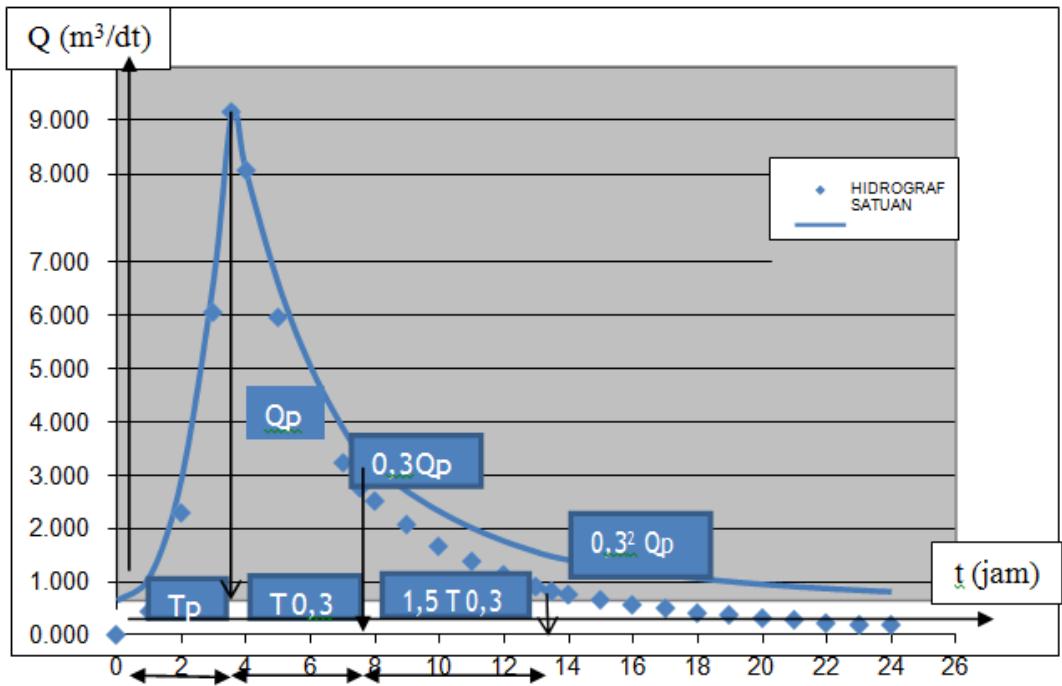

Figure 1. Nakayasu unit hydrograph

\section{Calculation of Flood Discharge Period}

Return period flood discharge is sought to anticipate the risk of flooding in the range of $2,5,10,20,50$ and 100 years from the maximum daily rainfall data in the Cisanggarung watershed.

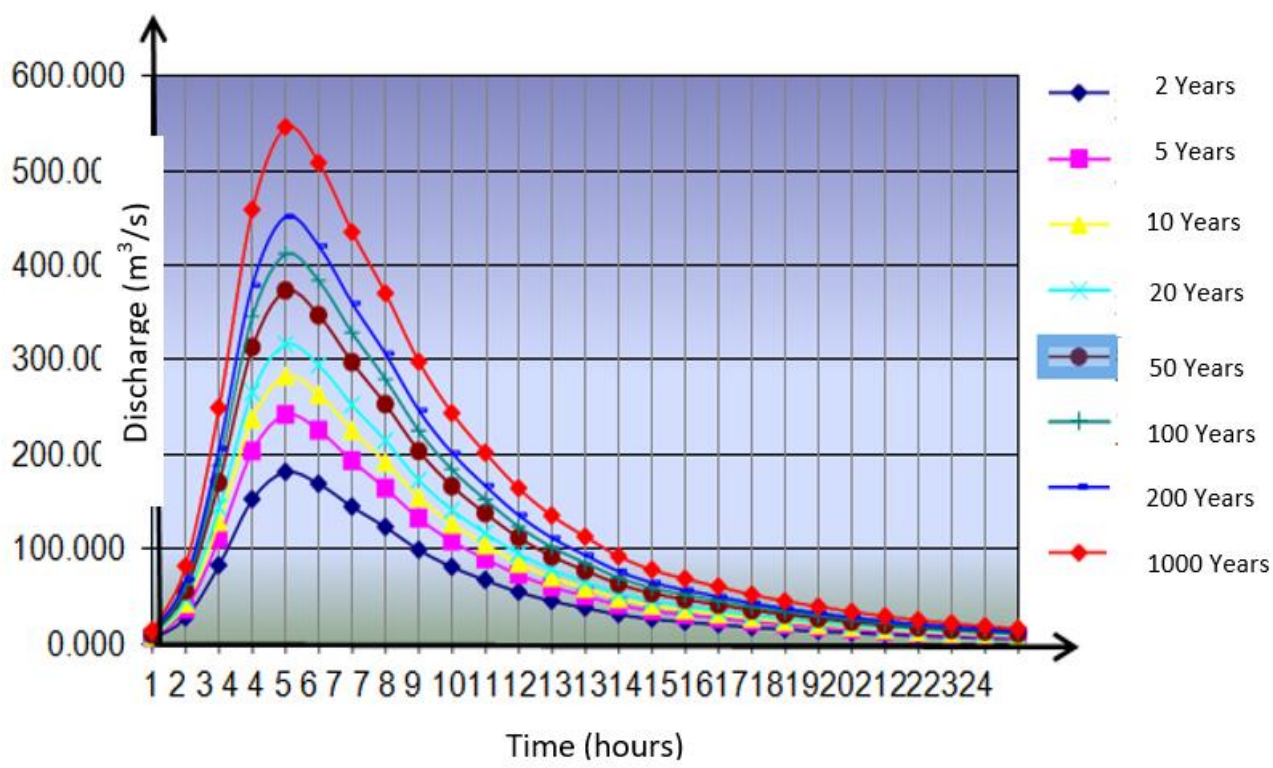

Figure 2. Return period flood discharge hydrograph

Figure 2 shows the relationship between the return period flood discharge and peak time. Of all the return periods, the largest flood discharge occurs at the 4th hour called the peak time. The amount of flood discharge each return period can be seen through the graph.

\section{Maximum 2 Daily Floods Debit Discharge}

Calculation of flood discharge is used to determine whether annual flooding from 2 
daily rains has the potential to cause flooding in the annual return period. Calculation of flood period return based on annual 2 daily maximum regional rainfall using the Tadashi Tanimoto rain distribution. The Tadashi Tanimoto method is an analytical method that utilizes clock weather data in Java using 8 (eight) hours rain time.

The process of calculating regional rainfall from the 2 annual maximum daily rainfall is the same as the calculation of the annual maximum daily rainfall. The maximum rain area is chosen from both rain stations. Hydrograph analysis is the same, only using 48 hours of rain with 8 hours of rain. The resulting hydrograph unit must be divided by the correction factor to make the hydrograph unit per one millimeter. Hydrographic unit correction factor is the ratio between the volume and area of the watershed. The Nakayasu unit hydrograph unit obtained is multiplied by the rain distribution factor. After an annual flood discharge is obtained based on 2 annual maximum daily rains, the results are compared with Q2, Q5 and Q10 flood discharges (see Figure 3).

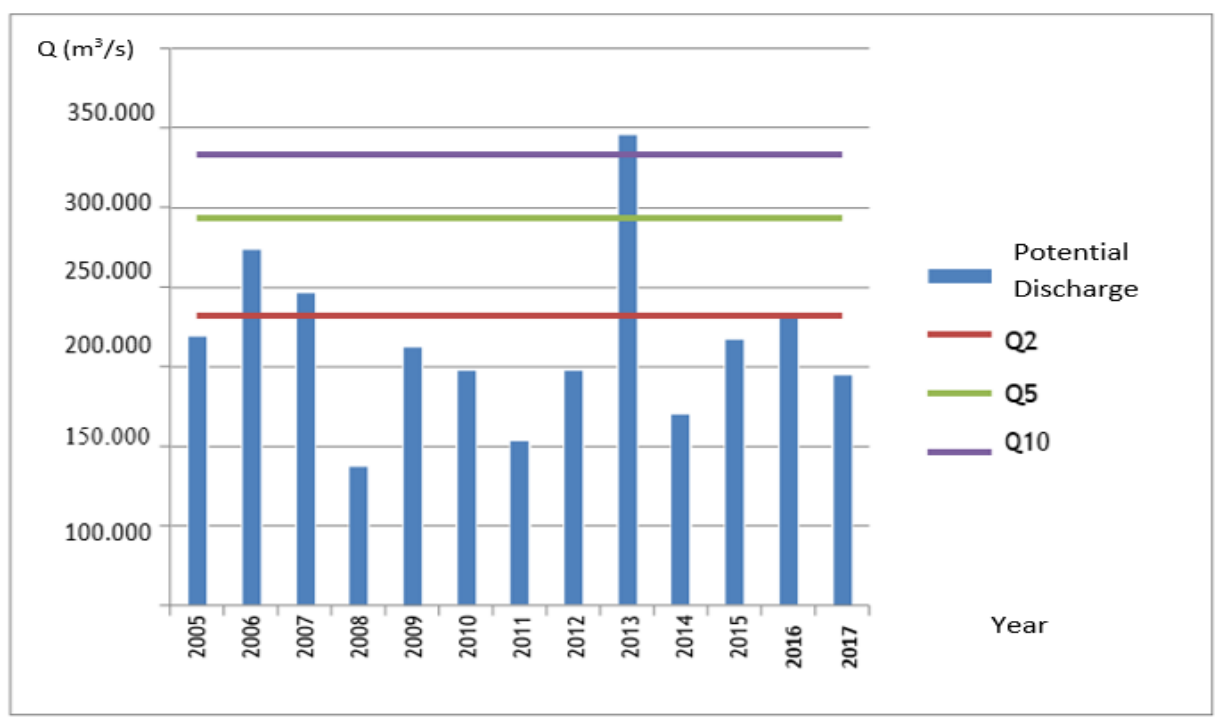

Figure 3. Comparison of annual 2-day flood discharge and return period flood

Figure 3 shows a comparison graph between the annual 2-day flood discharge and the return period flood. Annual data was taken from 2005-2017 (for 13 years). The results show that in 2005, 2007, 2009-2010, 2012 and 2014-2016 experienced the potential for Q2 flooding. In 2006, the area had the potential to flood Q5, while in 2013 it had the potential to flood Q10. The graph in Figure 3 can be concluded as in Table 6.

Table 6. The 2-Day recapitulation of flood discharge

\begin{tabular}{|c|c|c|}
\hline Year & $\begin{array}{c}\text { Discharge } \\
\left(\mathrm{m}^{3} / \mathrm{s}\right)\end{array}$ & Conclusion \\
\hline 2005 & 168.756 & Approaching the 2 yearly flood \\
\hline 2006 & 223.204 & Approaching the 5th annual flood \\
\hline 2007 & 195.823 & Approaching the 2 yearly flood \\
\hline 2008 & 86.789 & Does not cause flooding \\
\hline 2009 & 162.344 & Approaching the 2 yearly flood \\
\hline 2010 & 147.130 & Approaching the 2 yearly flood \\
\hline 2011 & 103.182 & Does not cause flooding \\
\hline 2012 & 147.619 & Approaching the 2 yearly flood \\
\hline 2013 & 295.085 & Approaching the 10th annual flood \\
\hline 2014 & 119.576 & Does not cause flooding \\
\hline
\end{tabular}




\begin{tabular}{|c|c|c|}
\hline Year & $\begin{array}{c}\text { Discharge } \\
\left(\mathbf{m}^{3} / \mathbf{s}\right)\end{array}$ & Conclusion \\
\hline 2015 & 166.504 & Approaching the 2 yearly flood \\
2016 & 183.221 & Approaching the 2 yearly flood \\
2017 & 144.648 & Approaching the 2 yearly flood \\
\hline
\end{tabular}

\section{Monthly 2-Day Flood Discharge}

Rain distribution for monthly 2-day plan discharge was analyzed using the Tadashi Tanimoto distribution. Average rain is calculated using the sum of 2 consecutive days each month (for 13 years) and the region's average rainfall is taken. The maximum 2 days monthly rainfall is shown in Table 7.

Analysis of monthly 2-day regional rainfall uses the Tadashi Tanimoto rain distribution by utilizing hourly rain data in Java using 8 (eight) hours rain time. As for knowing the effective rain hourly times, the multiplication between effective rain and the Tadashi Tanimoto distribution percentage is used.

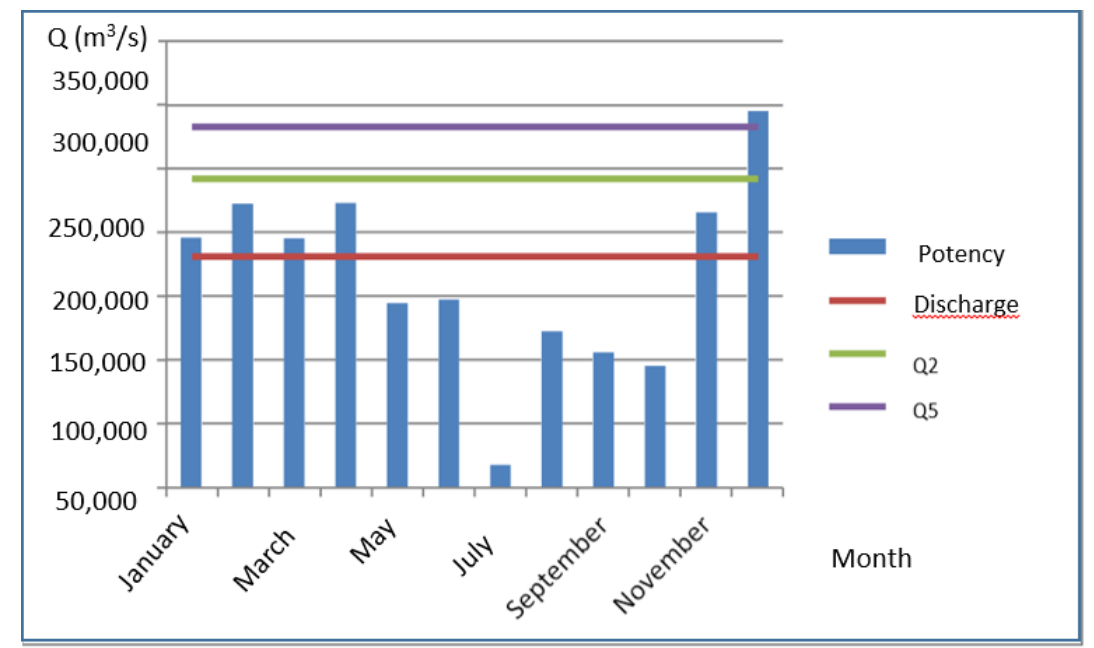

Figure 4. Comparison graph of annual maximum monthly flood and return period floods

Table 7 . Monthly 2-day flood discharge recapitulation

\begin{tabular}{|c|c|}
\hline Month & Discharge $\left.\mathbf{~}^{\mathbf{3}} \mathbf{/ s}\right)$ \\
\hline January & 195.823 \\
\hline February & 222.489 \\
\hline March & 195.260 \\
\hline April & 223.204 \\
\hline May & 144.648 \\
\hline June & 147.619 \\
\hline July & 18.030 \\
\hline August & 122.469 \\
\hline September & 105.925 \\
\hline October & 95.468 \\
\hline November & 215.608 \\
\hline December & 295.085 \\
\hline
\end{tabular}

Next, calculate the hydrograph unit by dividing it by the correction factor to make the hydrograph unit per one millimeter. Hydrographic unit correction factor is the ratio between the volume and area of the watershed. The Nakayasu unit hydrograph unit obtained is multiplied by the 8-day rain distribution factor which has been multiplied by the runoff 
coefficient.

After obtaining the annual maximum flood discharge, the data was compared to the flood discharge Q2, Q5 and Q10. The chart above shows that in January-April and November there is a potential for Q2 flooding. Whereas December could potentially flood Q10 (see Figure 4).

\section{CONCLUSIONS}

From the results of the analysis and calculation, the rain distribution in the Cisanggarung River Basin follows the Log Pearson Type III rain distribution pattern. The results of the calculation of flood return period using the Nakayasu method are Q2 $=181.518$ $\mathrm{m}^{3} / \mathrm{s}, \mathrm{Q} 5=242.498 \mathrm{~m}^{3} / \mathrm{s}, \mathrm{Q} 10=283.109 \mathrm{~m}^{3} / \mathrm{s}, \mathrm{Q} 20=316.534 \mathrm{~m}^{3} / \mathrm{s}, \mathrm{Q} 50=373.369 \mathrm{~m}^{3} / \mathrm{s}$, $\mathrm{Q} 100=412.425 \mathrm{~m}^{3} / \mathrm{s}, \mathrm{Q} 200=452.013 \mathrm{~m}^{3} / \mathrm{s}, \mathrm{Q} 1000=546.683 \mathrm{~m}^{3} / \mathrm{s}$. Annual flood data based on 2 annual maximum rainfall states that 2005, 2007, 2009-2010, 2015, 2009-2017 has the potential to flood Q2, 2012 has the potential to flood Q5, and 2017 has the potential to flood Q10. Meanwhile, monthly flood data based on 2 daily maximum rainfall states that 2005-2007, January-April and November have the potential to flood Q2, and December has the potential to flood Q10. The magnitude of the plan discharge and the potential flood that have been obtained can predict future floods, so that it can urge the public to anticipate the existence of floods in the following years.

\section{REFERENCES}

[1] Anonim. (2018). Cisanggarung. Retrieved January 31, 2020, from http://www.id.wikipedia.org/wiki/Ci_Sanggarung

[2] Badan Nasional Penanggulangan Bencana. (2013). Bencana di Indonesia 2012.

[3] Hadidhy, H. E. (2010). Analisis Pengaruh Bendung Terhadap Tanggul Banjir Sungai Ular. In Final Report. Medan: Universitas Sumatera Utara.

[4] Jayadi, R. (2000). Dasar-dasar Hidrologi. In Diktat Kuliah. Yogyakarta: Universitas Gadjah Mada.

[5] Rosyidie A. 2013. Banjir: Fakta dan Dampaknya, serta Pengaruh dari Perubahan Guna Lahan. Jurnal Perencanaan Wilayah dan Kota, 24 (3), 241-249.

[6] Setyowati, R. (2015). Status Kualitas Air DAS Cisanggarung Jawa Barat. Al-Ard: Jurnal Teknik Lingkungan, 1 (1), 37-45.

[7] Sihotang, R. H. (2015). Analisis Banjir Rancangan Dengan Metode HSS Nakayasu Pada Bendungan Gintung. Proceeding PESAT (Psikologi, Ekonomi, Sastra, Arsitektur \& Sipil) Universitas Gunadarma. 4 (2011) ISSN: 1858-2559.

[8] Sobriyah. (2003). Pengembangan Model Perkiraan Banjir Daerah Aliran Sungai Besar Dari Sintesa Beberapa Persamaan Terpilih. In Desertasi. Yogyakarta: Universitas Gadjah Mada.

[9] Soemarto, C. (1987). Hidrologi Teknik. Surabaya: Usaha Nasional.

[10] Sugiyono. (2009). Metode Penelitian Kuantitatif, Kualitatif, dan R\&D. Bandung: Alfabeta.

[11] Suripin. (2004). Sistem Drainase Perkotaan yang Berkelanjutan. Yogyakarta: Andi Offset.

[12] Utomo, W. (2012). Model Penelusuran Banjir Daerah Aliran Sungai Bengawan Solo Hulu 3 Dengan Menggunakan Gelombang Dinamis. In Skripsi. Surakarta: Universitas Negeri Sebelas Maret. 